\title{
Mercenaries Reloaded? Applicability of the Notion of 'Mercenaries' in Relation to Private Military Companies and their Employees
}

\begin{abstract}
The purpose of this study is to present the notion of mercenaries laid down in literature and in international law, as its applicability to private military companies and their employees so. The first chapter examines the use of the notion of mercenaries in literature and in international treaties. It explores whether the definition laid down in international treaties, reflect customary international law, or not. The second chapter of the study scrutinizes the various conditions listed in the afore-mentioned notions and tries to find out whether and to what degrees private military companies and their employees meet them. The final conclusion of this paper-of the perspective of international law-is that private military companies and their employees, in accordance with the rules of international law, cannot be considered mercenaries.
\end{abstract}

Keywords: mercenary, private military companies, combatants, Additional Protocol I, international humanitarian law, contractor, motivation, direct participation in hostilities

\section{Introduction}

"Mercenaries and auxiliaries are useless and dangerous; and if one holds his state based on these arms, he will stand neither firm nor safe; for they are disunited, ambitious and without discipline, unfaithful, valiant before friends, cowardly before enemies..."1-writes Machiavelli in his groundbreaking work, The Prince, giving substratum to numerous thinkers of contemporary international special literature, ${ }^{2}$ who are concerned with the outsourcing of military activities. This clearly shows that the subject is critical and problematical in various relations. However, reality requires to unfold another side of the question, namely that "PMC-s do not follow the heritage of mercenaries. By national financing they end such conflicts that must not unfold." 3

By taking this thought into consideration-besides that the topic is situated in various disciplines' (legal science, military science and security policy) scope-current study's aim is to investigate the applicability of the concept of mercenaries determined by international law in relation to private military companies and their employees. The first part of the study focuses on the concept of mercenaries under the examination of literature and international law's contractual rules. Furthermore, it strives to answer the question whether the international legal concept of mercenaries is part of customary law or not. The second part studies the applicability of the concept's every element with regards to contractors.

* PhD Student. Assistant lecturer. Széchenyi István University, Faculty of Law and Political Sciences, Department of Administrative and Financial Law. H-9026 Györ, Egyetem tér 1.

E-mail: janos.kalman88@gmail.com

1 Machiavelli, N.: A fejedelem. Budapest, 2006. 61.

2 See Gulam, H.: The rise and rise of Private Military Companies. http://media.peaceopstraining. org/t heses/gulam.pdf (12. 06. 2013.) 3.

3 Beutel, M. D.: Private Military Companies: Their emergence, importance, a call for global regulation (thesis). http://princess.digitalfreaks.org/thesis/beutelmdthesis.pdf (12. 06. 2013.) 10. 
In the study, the concepts of private military companies or PMSCs (private military and security company) mean enterprises with legal personalities, under employer or contractor we mean a natural person. Furthermore, all enterprises providing military or security service for supplying national duty are handled under the notion of private military companies. $^{4}$

\section{Concept of mercenaries in literature and international law}

When investigating that who and when can be regarded as a mercenary, we ought to be extremely careful, as the notions included in domestic and international literature consider those circles and people who fall within the scope of the notion wider than contractual and customary law of international law. They use wide enough notions in order to consider employees of private military companies as mercenaries. Therefore, it is not by chance that international media tends to mix contractors with mercenaries. ${ }^{5}$

\subsection{The notion of mercenaries in literature}

When clarifying the definition of mercenaries, we take a wider range of data, that is, the ideation of literature as a basis. The reason for this is that the subject of this investigation is a recent phenomenon connected to various disciplines and when analyzing it, it is practical to take theoretical definitions as a base. Hereby, the difference between theoretical ideation and international law regulating national practice can be emphatically highlighted.

In the broadest sense, those people may be regarded as mercenaries, who fight for financial gain in foreign wars; they are primarily used by armed groups and occasionally by governments, as well. ${ }^{6}$ It is clear that this notion's dominant element is the motive of gaining wealth, which makes the circle of people belonging to this group unduly wide. It needs to be narrowed down.

Laurie Nathan defines mercenaries as: people, who-in favour of money-serve a foreign country's army or a movement leading to an armed conflict-whether participating directly in fights or indirectly, by training, logistical assistance, secret agent activity or consultancy-and fall outside of the scope of authority of one's own country's government and protection. ${ }^{7}$ Besides the motive of gaining wealth, independency from its army also plays part in it.

By further narrowing down the concept, according to Scott C. Goddard, we can regard that person or organization as mercenaries who (or which) is financed to accomplish tasks within a foreign entity's military scope-also referring to participation in military-like action-without taking into consideration any kind of ideology, legal or moral obligation or

${ }^{4}$ The author is aware of the differences between military and security companies, either in their concept, or functions, but according to the study's topic it is dispensable to consider them together.

5 See Scahill, J.: Blackwater. The Rise of the World's Most Powerful Mercenary Army. New York, 2008.

${ }^{6}$ Center for Humanitarian Dialogue: Small Arms and Human Security Bulletin, Issue 3, 2004 http://www.hdcentre.org/publications/small-arms-and-human-security-bulletin-issue-n $\% \mathrm{C} 2 \% \mathrm{~B} 03$ (18. 07. 2012.) 2 .

7 Nathan, L.: Lethal Weapons: Why Africa needs alternatives to hired guns Track Two, 6 (1997) $2,10-12$. 
rules of domestic or international law. ${ }^{8}$ Compared to what has been previously stated, this concept points out to the amoral and illegal side of mercenaries' activity.

And finally, one of the most complex notions comes from Ervin Frigyes, who states that "Mercenaries are those people or groups of those people-united in different organizational units - who perform military (martial, military training, strategic and tactical planning, connected to martial weapons' maintenance and operation) activity without all kinds of ethnical, nationality, ideological or regional bonds, exclusively for material renumeration and are only motivated by financial interests for any clients-who pays them out." 9

After listing the above notions we can state that everyone emphasizes financial motivation as mutual element and surplus ones (for instance lack of ideology or illegal characteristics) are gathered under this concept. Employees of private military companies can be regarded as part of these notions without further investigation, hereby, they can be regarded as mercenaries. However, this could only be established with a superficial investigation. From humanitarian legal point of view, in case of an armed conflict it is matter of life and death whether a person can be regarded as mercenary or not. Notions of literature cannot be seen as basic of labelling, therefore, we ought to closely examine the rules of international law.

\subsection{Notion of mercenaries in international treaties}

Three international treaties deal with the notion of mercenaries: 1.) 1977 Protocol Additional to the Geneva Conventions of 12 August 1949, and relating to the Protection of Victims of International. Armed Conflicts (hereinafter: Additional Protocol I) ${ }^{10}$ 2.) the 1977 Organization of African Unity Convention for the Elimination of Mercenarism in Africa (hereinafter: African Union Convention); ${ }^{11}$ and 3.) 1989 International Convention against the Recruitment, Use, Financing and Training of Mercenaries that was meant to be universal (hereinafter referred to as UN Convention). ${ }^{12}$

Additional Protocol I was the first international treaty that aimed at clearing up the question of mercenaries. It sought to confine mercenaries among frameworks by stating that they cannot be regarded either as combatants or as prisoners of war. ${ }^{13}$ Above these, mercenaries are defined by Article 47 as any person, who:

${ }^{8}$ Goddard, S. C.: The Private Military Company: A Legitimate International Entity Within Modern Conflict (Thesis). Forth Leavenworth, Kansas, Faculty of the U.S. Army Command and General Staff College, 2001. http://www.globalsecurity.org/military/library/report/2001/pmclegitimate-entity.pdf (18. 07. 2012.) 8.

9 Frigyes, E.: Magánosítás, katonaság, katonai magánvállalkozások (Privatization, military, private military companies). Új Honvédségi Szemle, 2001/5.

10 Protocol Additional to the Geneva Conventions of 12 August 1949, and relating to the Protection of Victims of International Armed Conflicts, Geneva, 1977, UN Reg. No. 17512.

11 Organization of African Unity Convention for the elimination of mercenarism in Africa, Libreville, 1977, UN Reg. No. I-25573.

12 International Convention Against the Recruitment, Use, Financing and Training of Mercenaries, New York, 1989. december 4., UN Reg. No. 37789.

13 The diplomatic conference, which was agreed in Additional Protocol I, was not unanimous as regards the notion of mercenaries. Some delegations favoured a short and simple definition of a mercenary, because of the danger that qualifications might empty the concept of any real meaning. Other delegations, by calling for an enumeration of the criteria for a mercenary and by noting that 
a) Is specially recruited locally or abroad in order to fight in an armed conflict;

b) Does, in fact, take a direct part in the hostilities;

c) Is motivated to take part in the hostilities essentially by the desire for private gain and, in fact, is promised, by or on behalf of a Party to the conflict, material compensation substantially in excess of that promised or paid to combatants of similar ranks and functions in the armed forces of that Party;

d) Is neither a national of a Party to the conflict nor a resident of territory controlled by a Party to the conflict;

e) Is not a member of the armed forces of a Party to the conflict; and

f) Has not been sent by a State which is not a Party to the conflict on official duty as a member of its armed forces.

It emerges from the wording that in order to regard someone as a mercenary-therefore being able to part from combatants and civilians-one has to correspond to six conjunctive conditions. From this we can also conclude that if employees of private military companies do not correspond to even only one condition, they cannot be labelled as mercenaries, that is, they must be put in the category of combatants or civilians. However, we bump into a problem here, as employees of private military companies take place somewhere between these two categories and their international legal regulations are hardly satisfying. That is why they use "grey area" in international literature to describe operational area of contractors, as partly their operation is regulated and partly it operates freely. ${ }^{14}$

The African Union Convention practically takes over the notion of Article 47 of Additional Protocol I word by word, and sets the same conjunctive terms for qualifying someone as a mercenary. ${ }^{15}$

The application circle of the UN Convention is wider than that of the other two. This treaty created much wider and comprehensible notions. It labels two categories of people as mercenaries. The first category corresponds to the above-mentioned criteria, except that the direct participation in fights is not a condition. ${ }^{16}$ According to the second criterion, a mercenary is also any other person, who in any other situation:

a) Is specially recruited locally or abroad for the purpose of participating in a concerted act of violence aimed at:

i. Overthrowing a Government or otherwise undermining the constitutional order of a State; or

ii. Undermining the territorial integrity of a State;

certain types of individuals should be excluded from the definition, lent support to a more detailed and elaborate definition. See Official Records of the Diplomatic Conference on the Reaffirmation and Development of International Humanitarian Law Applicable in Armed Conflicts, Geneva (19741977), Vol. XV, Committee III Report, CDDH/236/Rev. 1. 97. http://www.loc.gov/rr/frd/Military_ Law/RC-dipl-conference-records.html (05. 06. 2013.).

${ }^{14}$ Liu, Hin-yan: Leashing the Corporate Dogs of War: The Legal Implications of the Modern Private Military Company. Journal of Conflict \& Security Law, 15 (2010) 1. http://ssrn.com/abstract $=1599073$ (31. 05. 2013.) 159.; Crawford, E.: The Civil-Military Interface in 21st Century Armed Conflict-Private Military Contractors and the Principle of Distinction. Sydney Law School Research Paper, (2011) 11/45, http://ssrn.com/abstract=1909666 (31. 05. 2013.) 3; Del Prado, J. L. G.: Private Military and Security Companies and the UN Working Group on the Use of Mercenaries. Journal of Conflict \& Security Law, 13 (2008) 3.

15 African Union Convention Article 1.

16 UN Convention Article 1. 
b) Is motivated to take part therein essentially by the desire for significant private gain and is prompted by the promise or payment of material compensation;

c) Is neither a national nor a resident of the State against which such an act is directed;

d) Has not been sent by a State on official duty; and

e) Is not a member of the armed forces of the State on whose territory the act is undertaken.

As can be seen, we also talk about conjunctive conditions in this case as well, furthermore, in the case of point a) action must correspond to various conditions.

The African Union Convention and the UN Convention go further compared to Additional Protocol I in the sense that they declare it illegal and punish mercenaries, their recruitment, training, financial support, and employment. ${ }^{17}$ However, it must be noted that in a UN Resolution from $1968^{18}$ it was declared that employing mercenaries against movements for national liberation and independence is punishable as a criminal act and that the mercenaries themselves are outlaws. Furthermore, it calls upon the Governments of all countries to enact legislation declaring the recruitment, financing and training of mercenaries in their territory to be a punishable offence and prohibiting their nationals from serving as mercenaries. The UN General Assembly further reconfirmed it in $1973 .{ }^{19}$

Already in 1984, International Law Commission regarded mercenaries as an international crime to the extent that the way this practice aims at violating states' sovereignty and governments' stability and at prevention of national liberation movements, it means crime against Peace and Security of Mankind. ${ }^{20}$

With regards to historical traditions as well, most states stayed away from the African Union Convention and the UN Convention, however, states mostly dispose of the question of mercenaries in their own domestic law. Hereby, Act IV of 1978 about the Criminal Code prohibits recruiting and punishing it in 154. §. Any attempt to recruit personnel in the territory of the Republic of Hungary for military service-other than for any allied forces-, paramilitary service in a foreign armed body, or any mediation of volunteers for such service shall be construed a felony and punishable by imprisonment between one to five years. Furthermore, any Hungarian citizen shall get the same punishment who voluntarily joins or offers to join any foreign armed body-other than the allied forces-that is involved in an armed conflict (national or international), or who participates in training in such an armed body.

Act C of 2012 about (the new) Criminal Code that came into effect on 1st July, 2013 takes over the previous regulation word by word, it only supplements it with a certified case as based on the 146 . $\S(3)$ that if in the territory of Hungary someone recruits people younger than 18-yearsold for military service to foreign armed forces, or to other service with military interest, or transmits applicants for similar service shall be sentenced to jail from two years to eight years. However, the new CC makes a dogmatic refinement, as it replaces it from crime against humanity to the group of war crimes. However, we can critically say about the operative and operative-to-be CC that the fact of illegal recruiting

17 Szalai, A.: A katonai magánvállalatok részvétele és jogállása a fegyveres konfliktusokban (The participation and the legal status of the private military companies in hostilities). Föld-rész, (2010) $1-2,40$.

18 UN Resolution A/RES/2465(XXIII).

19 UN Resolution A/RES/3103(XXVIII).

20 Dinh, N. Q.-Daillier, P.-Pellet, A.-Kovács, P.: Nemzetközi közjog (International public law). Budapest, 2005. 462. 
does not punish financial support of foreign armed forces, and it can only be connected to supporting the opponent's state of affairs, if the financial support materializes with the aim of weakening Hungary's military strength.

Based on investigating international treaties we can determine that in each of them, the definition of mercenaries is based on Additional Protocol I. They follow the same scheme; they list numerous conditions which all need to be met to label someone as a mercenary. ${ }^{21}$ However, many states stayed away from the African Union Convention and the UN Convention-as we have previously mentioned-so the following question will be that whether we can regard the notion of mercenaries based on Additional Protocol I as customary law, hence, compulsory for each state.

\subsection{Notion of mercenaries in international customary law?}

According to the study be the International Committee of the Red Cross about international humanitarian customary law the notion of mercenaries written in Additional Protocol I is part of customary law these days. Pursuant to the Rule 108 mercenaries, as defined in Additional Protocol I, do not have the right to combatant or prisoner-of-war status. However, they may not be convicted or sentenced without previous trial. ${ }^{22}$

However, answering the question is not so easy, possible reasons for the statement of International Committee of Red Cross needs to be investigated. First of all, Additional Protocol I is one of the most widely ratified international treaties. It was ratified by 173 states until the summer of 2013; among them are the states of the European Union, China, The Russian Federation, Japan or Brasil. ${ }^{23}$ Four of five permanent members of UN Security Council. ${ }^{24}$ None of the states had reservation regarding the notion framed in Article 47 of Additional Protocol I. Out of the 28 states of NATO $26,{ }^{25}$ plus all three states waiting for joining ${ }^{26}$ ratified the protocol. With regards to international conflicts, governments, UN Commissions, and International Committee of the Red Cross frequently recalls the Additional Protocol I. ${ }^{27}$ Military manuals of many countries, for instance Argentina, Australia, Belgium, France, the Netherlands or Spain contain a definition of mercenaries that is identical to the one provided by Article 47 Additional Protocol I. ${ }^{28}$

${ }^{21}$ Mancini, M.: Private military and security company employees: Are they the mercenaries of the twenty-first century? EUI Working Paper, AEL 2010/5. http://papers.ssrn.com/sol3/papers.cfm?a bstract_id=1720543 (08. 06. 2013.) 4 .

${ }^{22}$ Henckaerts, J.-M.-Doswald-Beck, L.: Customary International Humanitarian Law, Volume I: Rules. Cambridge, 2005. http://www.icrc.org/eng/assets/files/other/customary-internationalhumanitarian-law-i-icrc-eng.pdf (05. 08. 2013.) 391.

23 The complete list of the ratifing countries: http://www.icrc.org/applic/ihl/ihl.nsf/States. xsp?xp_view States=XPages_NORMStatesParties\&xp_treatySelected=470 (19. 06. 2013.).

${ }^{24}$ United Kingdom, France, China, Russia.

25 The two exeptions are the United States of America and Turkey.

26 Georgia, Macedonia, Ukrain.

27 Scharf, M. P.: The ICC's Jurisdiction Over the Nationals of Non-Party States: A Critique of the U.S. Position. Law and Contemporary Problems, 64 (2001) 1, http://scholarship.law.duke .edu/ cgi/viewcontent.cgi?article $=1201 \&$ context $=1 \mathrm{cp}$ (26. 05. 2013.) 93 .

${ }^{28}$ Henckaerts, J.-M.-Doswald-Beck, L.: Customary International Humanitarian Law, Volume II: Practice. Cambridge, 2005. http://www.icrc.org/eng/assets/files/other/customary-internationalhuma nitarian-law-ii-icrc-eng.pdf (27. 05. 2013.) 2576. 
Arguments next to the customary-like nature of the notion of mercenaries can be convincing, as for the first sight they can suggest that two elements of custom creation of law: "general practice" and "legal conviction", the opinio iuris sive necessitatis. However, the second element needs to be further examined, as beyond repetition, existence of conscience of legal obligation is also a condition. ${ }^{29}$

When listing the above-mentioned conditions, it may come into view that the United States of America has not been mentioned. The reason for this is that the USA did not ratify the Additional Protocol I, only signed it. However, based on Article 18 of Vienna Convention on the Law of Treaties 1969, states are obliged to refrain from acts which would defeat the object and purpose of a treaty, however, lack of ratification by all means represents that the USA does not agree with the Additional Protocol I, or one of its regulations. Moreover, Deputy Legal Adviser of the US Department of State affirmed that "we do not favor the provisions of article 47 on mercenaries, which among other things introduce political factors that do not belong in international humanitarian law, and do not consider the provisions of article 47 to be part of current customary law". ${ }^{30}$ Based on this, the USA, as a persistent objector, based on its sovereignty, can pull itself out from the obligatory strength of general customary law, if we accept the customary nature of the notion of mercenaries. In an opposite situation we do not even need to climb all of these steps.

However, it is not exclusively the USA which does not agree with what is being said in Article 47 of the Additional Protocol I and its custom-like characteristic. ${ }^{31}$ When ratifying the Additional Protocol I in 1989, Algeria even attached interpretative declarations to the document. In it the country explains that the Government of the People's Democratic Republic of Algeria reserves judgement on the definition of mercenarism as set out in Article 47, para 2 of the present Protocol, this definition being deemed restrictive. ${ }^{32}$ Similarly to Algeria, Cuba attached a statement to the UN Convention, in which it explains that it does not agree with the notion of mercenaries-based on Additional Protocol I-defined in the Convention and will further stick to the notion defined in the 1988 Criminal Code. ${ }^{33}$

To summarize the above-mentioned pros and contras, we can say that the custom-like characteristic of mercenaries can be questioned. However, it does not reduce from the value of the notion written in Additional Protocol I; as it is an especially widely ratified international treaty, which provisions are compulsory for member countries. As for further investigations, conceptual elements of Article 47 are the standard in contrary to wide and easy to shape notions of literature. Thus, hereinafter, we will investigate elements of Additional Protocol I; and will attempt to answer the question whether employees of private military companies can be included in this circle or not.

29 Dinh-Daillier-Pellet-Kovács: op. cit. 167.

30 Henckaerts-Doswald-Beck: Customary International Humanitarian Law, Volume II: Practice. op. cit. 2579.

${ }^{31}$ However, it is not ambiguous that the USA is the most important objector, in connections with its military, economic and political potential.

${ }^{32} \mathrm{See}$ the interpretative declarations at http://www.icrc.org/ihl.nsf/NORM/ 983A7615F773CFC7C125 6402003FB232?OpenDocument (27. 05. 2013.).

33 See the statement: http://treaties.un.org/Pages/ShowMTDSGDetails.aspx?src= UNTSONLINE\&tabid=2\&mt dsg_no=XVIII-6\&chapter=18\&lang=en\#EndDec (27. 05. 2013.). 


\section{International legal qualification of private military companies and their employees}

In the media private military companies are labeled by such pejorative attributes as "dogs of war", "mercenaries", "soldiers of fortune", moreover, these words are also used by professionals in order to describe armed contractors who guard VIPs, convoys, oil lines and other institutions in places like Iraq or Afghanistan. ${ }^{34}$ This-and because of media incidents that worthily became well-known and notorious-they start to mix the notions of mercenaries and private military companies, in spite of the numerous differences between them.

However, it is significant that activities of private military companies and outsourcing of national military tasks are not free from historical antecedents. In mainland the institution of "condottieri", at sea the institution of "privateer" spread between the $13-19^{\text {th }}$ centuries.

Condottieri (meaning military employee) was the first form of organised European private armies. Its ancestry dates back to the $14^{\text {th }}$ century Italy. ${ }^{35}$ As a result of permanent military activities of knighthood that lost its privileges, a special system came into life, setting the art of armies into focus in armed conflicts and not the victory through sacrificing masses of soldiers. Condottieri practically formed a "military state". Their structure resembled of a perfectly organized business structure. ${ }^{36}$ Condottieri, called by Sobek as "mercenary-enterprise" 37 hired lawyers and notaries in order to clarify legal questions and to word contracts. They also hired accountants and bankers in order to handle incomes more effectively, and to raise them through investments. Based on these, we can say that there's a certain similarity between modern private military companies and condottieri, regarding business structure. However, it is a ground difference that small a number of private military companies provide actual armed services. ${ }^{38}$

Privateers-which are mostly incorrectly translated as pirates-were people, who carried out their tasks on sea, with the authorization of a state. This authorization is called Letter of Marque. The first charter was issued by Henry III, English ruler in 1243, well before forming the Royal Navy. ${ }^{39}$ The charter was practically a national authorization for private entrepreneurs to hold supplies of enemies during war; however, privateers also proved to be useful in fights against pirates or as a defensive unit, too. ${ }^{40}$ European states more and more increasingly hired these entrepreneurs through the centuries; ${ }^{41}$ their most significant role was during the American Revolutionary War. ${ }^{42}$ Their enforcement was prohibited by the Paris Declaration, accepted on 16 April, $1856 .{ }^{43}$

34 Baker, D.-P.: Just warriors, Inc. The Ethics of privatized force. New York, 2011. 31.

35 Smith, E. B.: The New Condottieri and US Policy: The Privatization of Conflict and Its Implications. Parameters, Winter 2002-03, 105.

${ }^{36}$ Kollárné Nényei, J.: A XXI. század praetoriánusai? Szakmai Szemle, (2009) 3, 139-140.

37 Sobek, D.: Machiavelli's Legacy: Domestic Politics and International Conflict. International Studies Quarterly, 49 (2005) 2, 201.

38 Kollárné Nényei: op. cit. 140.

39 Richard, Th. T.: Reconsidering the Letter of Marque: Utilizing Private Security Providers Against Piracy. Public Contract Law Journal, 39 (2010) 3, http://ssrn.com/abstract=1591039 (2012.08.30.) 423.

40 Ibid. 422.

${ }^{41}$ One of the well-known privateers was Sir Francis Drake.

${ }^{42}$ About their significant role see Ross, N. J.: The Provision of Naval Defense in the Early American Republic, A Comparison of the U. S. Navy and Privateers, 1789-1815. The Independent Review, 16 (2012) 3.

43 The Declaration stated that privateering is, and remains, abolished. 


\subsection{Comparison of private military companies with mercenaries}

The previous historical retrospection also revealed that entities similar to private military companies have already existed before and even then people tried to think of them as mercenaries. For that very reason, based on their characteristics, private military companies are needed to be compared to mercenaries.

The next table summarizes the basic differences between private military companies and mercenaries: ${ }^{44}$

\section{Table 1: Differences between mercenaries and PMSCs}

\begin{tabular}{|c|c|c|}
\hline Mercenaries & Characteristics & Private Military Companies \\
\hline $\begin{array}{l}\text { Try to stay away from public } \\
\text { attention }\end{array}$ & Publicity & $\begin{array}{l}\text { Transparent advertising and } \\
\text { offering of their service }\end{array}$ \\
\hline Small group of individuals & Form of organisation & $\begin{array}{l}\text { Corporative, business form, } \\
\text { legal personality }\end{array}$ \\
\hline $\begin{array}{l}\text { Usually foreign citizens, } \\
\text { terrorists, criminals, gorillas }\end{array}$ & Members & $\begin{array}{l}\text { Members usually have } \\
\text { previously served in national } \\
\text { armies, and are recruited from } \\
\text { multinational database }\end{array}$ \\
\hline "Bottom-up" & Form of violence privatisation & "Top-down" \\
\hline Direct offensive activity & Activity & $\begin{array}{l}\text { Training, professional guidance, } \\
\text { military intelligence, counter- } \\
\text { espionage, maintenance, logistic } \\
\text { support, military support, } \\
\text { military attendant support, or } \\
\text { reconstruction after conflicts }\end{array}$ \\
\hline Black market, cash & Condition of hiring & $\begin{array}{l}\text { Contracts, many times invitation } \\
\text { to tender }\end{array}$ \\
\hline
\end{tabular}

Training, hiring, financing and recruiting of mercenaries is prohibited by international law, hereby, their activity is done in highest security. In opposition to this, advertising and publicity are essential conditions of private military company activities. It is significant that they quasi also organised chambers in order to implement their self-regulation. ${ }^{45}$ Mercenaries are smaller groups of individuals, so the individual characteristic dominates, in opposition to PMSCs, which are mainly organized business ventures with legal personalities. Mercenaries are usually citizens of a foreign state and many times gerillas, criminals and terrorists also become members. Most employees of PMSCs have served in national armies before, and they are chosen for missions from multinational database. Mercenaries mostly represent violent form of privatisation that is built from bottom to top (bottom-up), their contracting parties are usually not nations or armed groups who aim at undermining constitutional order in countries. PMSCs take part in violent privatisation that is organized from top to bottom (top-down)-their contracting parties are mainly governments or

44 The table is made by the author and based on the work of Judit Kollárné Nényei. See Kollárné Nényei: op. cit.

45 Such an organisation is International Stability Operations Assosiation (ISOA), which was established in 2001. 
multinational companies, which mostly aim at improving reconstruction or strengthening inner order and safety. Mercenaries primarily take part in direct offensive activities, PMSCs only attend such tasks exceptionally, however, they carry out numerous other activities: training, professional guidance, military intelligence, counter-espionage, maintenance, logistic support, military support, military attendant support, or reconstruction after conflicts. Mercenaries-because of staying away from publicity-are used from black market and paid for in cash, PMSCs offer their services in public and enter into contracts with clients. National tasks are transacted via various application proceedings.

\subsection{Are contractors the mercenaries of the 21 st century?}

When comparing private military companies with mercenaries, the difference that does not allow the two to be mixed can be clearly seen. However, from international legal perspective, further investigation of the question is necessary, and applicability of mercenaries that has previously been mentioned, needs to be further studied with regards to employees of private military companies. That is, elements of the notion of mercenaries have to be studied one by one, namely, a) their recruitment, b) direct participation in hostilities, c) motivation, d) nationality and place of residence, e) membership of the armed forces, as a negative element.

\section{a) Recruitment}

Based on Additional Protocol I, Article 47. para 2, African Union Convention Article 1. para. 1 and UN Convention Article 1. para. 1 that person can be regarded as a mercenary, who is specially recruited locally or abroad in order to fight in an armed conflict. Based on the UN Convention Article 1. para. 2 that person also can be regarded as a mercenary, who is specially recruited locally or abroad for the purpose of participating in a concerted act of violence aimed at overthrowing a Government or otherwise undermining the constitutional order of a State; or undermining the territorial integrity of a State.

The wording of the treaties does not mention the recruiter, so it can even be a company which was entrusted by a state with supplying military or safety tasks in conflict zones. Contracts between companies and employees almost always remain a secret, however, contracts between states and companies are many times public. ${ }^{46}$

According to Louise Doswald-Beck, this one is one of the most problematic conceptual elements, as it is not entirely true that private military companies recruit people to take part in fights, not even if defensive-training tasks, installation of equipments stated in contracts results in it. Logically, if we look at the problem from international humanitarian law point of view, we can conclude that it does not matter what is being stated in private military company contracts, if they guard military institutions against enemies-not included selfdefence and acts against ordinary miscreants-they must be regarded as they were recruited in order to participate in fights. In this sense no difference exists between "offense" and "defence", if it happens during an armed attack. ${ }^{47}$ This problem relates to the one of direct participation in hostilities, so it will further be discussed later.

46 The short abstracts of the contracts which are exceeding 6.5 million dollars, are available at the website of the U. S. Department of Defence. See http://www.defense.gov/contracts/archive.aspx (2013.05.30.).

47 Doswald-Beck, L.: Private military companies under international humanitarian law. https:// lapa. princeton.edu/conferences/military07/restricted/doswald-beck_military07.pdf (31. 05. 2013.) 8 . 
Companies of military services usually do not maintain greater permanent infrastructure, hereby, recruiting happens via various channels. There are international databases about possible people to be asked, private military companies publish their actual job offers even on their websites, or they draw on in-between companies. ${ }^{48}$ These companies do the recruiting and training, they deliver the contractors to the conflict zones on behalf of the employer. ${ }^{49}$ Its outcome is an especially complicated, unperspicuous contractor - subcontractor structure,$^{50}$ which opens the door for misuse, in some cases, for violating human rights. Of course, sub-contractors have-respective to laws of their permanent residence's country-legal personalities. Independent legal personality excludes to call the "parent establishment" to account because of violation of law committed by its sub-contractors or its employees. ${ }^{51}$ We can conclude from Karácsony Veronika's interview with contractors that entering into a contract, detailed and final clarification of condition usually takes place on the territory of the action, after having started the job. ${ }^{52}$

From one side, employees of private military companies consist of thousands of soldiers from general reduction of armies, on the other side, from strengthening flow of soldiers due to change for professional army. Besides previous soldiers, past employees of police and other violent services also become employees in increasing numbers. ${ }^{53}$ However, this can be a problem, too. One UN Workshop called the attention to previous soldiers and policemen recruited to be "security men" who may become armed private soldiers in low intensity armed conflicts or in situations followed by conflicts. ${ }^{54}$

b) Direct participation in hostilites

Based on Additional Protocol I Article 47 para. 2 and African Union Convention Article 1 para. 1, second element of the notion of mercenaries is direct participation in the hostilities. However, a contrario, it is significant that Article I of UN Convention does not make direct participation in hostilities a conceptual element.

${ }^{48}$ Holmqvist, C.: Private Security Companies-The Case for Regulation. SIPRI Policy Paper, (2005) 9. http://books.sipri.org/files/PP/SIPRIPP09.pdf (05. 05. 2013.) 6.

${ }^{49}$ About occurred cases see: UN Doc. A/HRC/7/7/Add.2. Report of the Working Group on the question of the use of mercenaries as a means of violating human rights and impeding the exercise of the right of peoples to self-determination, Mission to Peru, 7; UN Doc. A/HRC/7/7/Add.3. Report of the Working Group on the question of the use of mercenaries as a means of violating human rights and impeding the exercise of the right of peoples to self-determination, Mission to Fiji, 9; UN Doc. A/ HRC/7/7/Add.4. Report of the Working Group on the question of the use of mercenaries as a means of violating human rights and impeding the exercise of the right of peoples to self-determination, Mission to Chile, 10; UN Doc. A/HRC/4/42/Add.1. Report of the Working Group on the question of the use of mercenaries as a means of violating human rights and impeding the exercise of the right of peoples to self-determination, Mission to Honduras, 7.

50 Crawford: op. cit. 10.

51 Ryngaert, C.: Litigating Abuses Committed by Private Military Companies. The European Journal of International Law, 19 (2008) 5, 1039.

52 Karácsony, V.: A biztonság privatizálása - Nemzetközi tapasztalatok és azok hatása a Magyar Honvédségre. (PhD thesis). http://193.224.76.2/downloads/konyvtar/digitgy/phd/2012/karacsony_ veronika.pdf (31. 05. 2013.) 76.

53 Varga, K.: Civilek a harcmezőn - katonai magánvállalatok. MKI-tanulmányok, T-2009/12. 9.

${ }^{54} \mathrm{UN}$ Doc. A/HRC/7/7. Report of the Working Group on the question of the use of mercenaries as a means of violating human rights and impeding the exercise of the right of peoples to selfdetermination 24 . 
From international humanitarian law point of view, determining of direct participation has a crucial role, as direct participation is the base of demarcation between military and civil inhabitants. Members of a state's armed forces (except medical and ecclesiastical personnel) and members of organized armed forces can usually be looked upon as legitimate military targets, except if, they surrender or become unable to fight in any other ways. Civil people are usually defended from direct offenses, except if, and for that period when they directly participate in hostilities. ${ }^{55}$

In spite of their significance, neither international humanitarian law's contractual regulations, nor the practice of governmental or international courts define exactly direct participation in fights. So, in order to study this conceptual notion, general regulation in respect to international humanitarian law needed to be used, that is a treaty shall be interpreted in good faith in accordance with the ordinary meaning to be given to the terms of the treaty in their context and in the light of its object and purpose. ${ }^{56}$

Recognising problems of defining direct participation, International Committee of the Red Cross initiated negotiations in 2003, which resulted in the publication of the document, entitled Interpretive Guidance on the Notion of Direct Participation in 2009. ${ }^{57}$

According to the Recommendation IV of the Interpretive Guidance, "the notion of direct participation in hostilities refers to specific act carried out by individuals as part of the conduct of hostilities between parties to an armed conflict." ${ }^{58}$ Furthermore, the Interpretive Guidance clarifies that this notion needs to be understood in the same way in connection to international and non-international armed conflicts as well.

In reality, direct participation in fights can come true in various forms and intensity, so when judging whether the behaviour counts as direct participation, every possible circumstance, so characteristics of the given place and time are also needed to be examined during the process. ${ }^{59}$

Why is it so important to highlight that the notion of direct participation only refers to defined behaviours? Because extension outside of defined behaviours of the notion of direct participation would threaten the international humanitarian law's distinction between continuous protection of filled status and loss of temporary protection because of action.

In order to define the relevant forms of behaviour, the Recommendation $\mathrm{V}$ provides help. "In order to qualify as direct participation in hostilities, a specific act must meet the following cumulative criteria:

1. the act must be likely to adversely affect the military operations or military capacity of a party to an armed conflict or, alternatively, to inflict death, injury, or destruction on persons or objects protected against direct attack (threshold of harm);

2. there must be a direct causal link between the act and the harm likely to result either from that act, or from a coordinated military operation of which that act constitutes an integral part (direct causation); and

55 Csapó, Zs.: Civil a pályán? Kommentár Az ellenségeskedésekben való közvetlen részvétel fogalmáról címü dokumentumhoz (Civils on the ground? Commentary to document titled Interpretative Guidance on the Notion of Direct Participation in Hostilities under International Humanitarian Law). Föld-rész, (2010) 1-2., 127.

56 Vienna Convention on the Law of Treaties, Vienna, 1969. Article 31 para. 1.

57 Melzer, Nils.: Interpretative Guidance on the Notion of Direct Participation in Hostilities under International Humanitarian Law. ISRC 2009. http://www.icrc.org/Web/eng/siteeng0.nsf/ htmlall/direct-participation-report_res/\$File/direct-participation-guidance-2009-icrc.pdf (31. 05. 2013.).

58 Melzer: op. cit. 1013.

59 Csapó: op. cit. 112. 
3. the act must be specifically designed to directly cause the required threshold of harm in support of a party to the conflict and to the detriment of another (belligerent nexus)." ${ }^{60}$

Thus, three conjunctive conditions must meet in order to define a stipulated behaviour as direct participation in hostilities: 1. causing mortification, 2. direct cause-effect relation between behaviour and mortification, 3. relationship between behaviour and hostility of parties to an armed conflict.

As we have previously mentioned it in connection with recruiting, private military companies many times refer to that they only offer protective services and do not participate directly in hostilities. However, protection also counts as direct participation in fights. International humanitarian law does not make any difference between offensive and defensive actions. ${ }^{61}$ This is only the other side of a coin. For instance in Iraq, private military companies had the tasks of protecting military institutions, which, in case of military targets and armed fights reaches the level of direct participation. ${ }^{62}$

Besides protective services, private military companies usually allude to that they only carry out preparatory activities, like arming, transportation, collecting information, etc. In this case the question is: when does direct participation in fights begin?

According to the Interpretive Guidance's Recommendation VI, "measures preparatory to the execution of a specific act of direct participation in hostilities, as well as the deployment to and the return from the location of its execution, constitute an integral part of that act." ${ }^{93}$ When judging direct participation, it is neither necessary, nor sufficient that 1. a preparatory measure occur immediately before (temporal proximity) or 2 . in close geographical proximity to the execution of a specific hostile act or that it be indispensable for its execution. ${ }^{64}$

Thus, we can establish that based upon the investigation of the first two conceptual notions, employees of private military companies cannot be parted from mercenaries. Criterion of recruiting and participation in fights are all accomplished by companies and their employees, too.

c) Motivation

Based on Additional Protocol I. Article 47 para. 2, African Union Convention Article 1 para. 1, the third element of mercenaries is financial motivation. According to the treaties' wording, mercenaries are people, who are motivated to take part in the hostilities essentially by the desire for private gain. Private gain is promised by or on behalf of the Party to the

${ }^{60}$ Melzer: op. cit. 1016.

${ }^{61}$ Gillard, E.-Ch.: Business goes to war: private military/security companies and international humanitarian law. International Review of the Red Cross, Vol. 88 (2006) 863, 540.

62 As we have mentioned before, private military companies many times refer to that they only offer protective services and do not participate directly in hostilities. The facts are just the opposite. In October 2007, an oversight panel of the United States House of Representatives released a report indicating that Blackwater employees had been involved in at least 196 fire-fights in Iraq since 2005, an average of 1.4 shootings per week. In 84 per cent of those cases, the reports stated, Blackwater employees opened fire first, despite contract stipulations to make use of force only in self-defence. See UN Doc. A/63/325 Note by the Secretary-General transmitting the report of the Working Group on the use of mercenaries as a means of violating human rights and impeding the exercise of the right of peoples to self-determination (25 August 2008) 9.

63 Melzer: op. cit. 1031.

64 Ibid. 1032. 
conflict, material compensation substantially in excess of that promised or paid to combatants of similar ranks and functions in the armed forces of that Party. Hence, this is also a conjunctive condition, too. Therefore, necessary are: 1.) individual desire for private gain, 2.) private gain must be promised by or on behalf of the Party to the conflict and 3.) material compensation substantially in excess of that paid to soldiers in the armed forces.

Article 1 para. 2 of UN Convention only supplements financial motivation with a highly questionable attribute; it demands "significant" personal profit from mercenaries.

Previously, when reviewing literature notions, we noticed that financial motivation as differentia specifica was highlighted by every author. In the case of international legal investigation of the notion of mercenaries, it is the same, too, as financial motivation is the most crucial element of conceptual criteria laid down in treaties. This has already been highlighted during preparations of Additional Protocol I. ${ }^{65}$ Financial motivation makes it possible to terminate mercenaries from volunteers joining armies, who are mostly not motivated by gaining wealth but by noble beliefs. ${ }^{66}$ Although it is questionable whether we can terminate employees of private military companies from mercenaries, when we investigate their motivation.

Let us start with the first part of the conceptual notion, the individual desire for private gain. One of the UN research groups arrived at the conclusion after their research that primarily motivation of military employees is gaining financial wealth. ${ }^{67}$ However, this does not need to be morally condemned, as great amount of private military company employees are recruited from developing countries or states with high percentages of unemployment. It further needs to be noted that gaining wealth is not an exclusive motivation. Desire for adventure, continuing military services (e.g. in case of vets) or simply proposition of doing something can mean nearly similar motivation. ${ }^{68}$ During her research, Veronika Karácsony arrived at the conclusion that "previous soldiers and police men undertake jobs in private military companies because of professional improvement and gaining experience, or great cut-backs or constraint superannuations". ${ }^{69}$ Based on these, we can talk about motivational mixture of private military company employees, in which gaining wealth is a significant but not an exclusive element.

65 See Official Records of the Diplomatic Conference on the Reaffirmation and Development of International Humanitarian Law Applicable in Armed Conflicts, Geneva (1974-1977), Vol. XV. Committee III Report, CDDH/236/Rev. 1. 99. "Most important of all a mercenary is a person who is motivated to fight essentially or primarily by the desire for, as one representative put it, 'hard cash'. He fights for monetary gain whether it be higher pay than is given to the regular armed forces of the state or by way of bonuses for persons killed or captured. The definition must be so framed, however, that the individual who enlists as a regular member of the armed forces because he is attracted by good pay is not on that account deemed to be a mercenary."

66 Sandoz, Y.-Swinarski, Ch.-Zimmermann, B. (ed.): Commentary on the Additional Protocols of 8 June 1977 to the Geneva Conventions of 12 August 1949. ICRC, Geneva, 1987, 615.

$67 \mathrm{UN}$ Doc. A/HRC/7/7. Report of the Working Group on the question of the use of mercenaries as a means of violating human rights and impeding the exercise of the right of peoples to selfdetermination, 15.

${ }^{68}$ Kascakova, D.: Mercenaries reconsidered-The Ethics and the Future Role of Private Military Companies. ISA Annual Convention, 2011. http://www.allacademic.com/meta/p502121_index.html (05. 05. 2013.) 16.

69 Karácsony: op. cit. 77. 
The second part refers to the origin of financial remuneration as it must be promised by or on behalf of the Party to the conflict. From theoretical point of view, this element is the least problematic one, as only the road of money needs to be backtracked, and if the fighting party can be found in the chain, this element comes true.

Finally, financial remuneration must significantly exceed the amount paid for soldiers of armed groups. They usually refer to that employees of private military companies significantly earn more than equal members of armies. ${ }^{70}$ The question is that whether employees of private military companies really partake in overpayment or not.

The question cannot be exactly answered, as great differences exist in payments of employees. According to Del Prado's research, employees can be organized into a hierarchical pyramid. At the top of the pyramid stand highly trained soldiers from the USA, who are the most greatly paid ones. Under them take place employees from Australia, United Kingdom, Canada and South-Africa, who are as well, greatly paid. On the third level we can find the so-called third country members (e.g. Chile, Nepal, Peru, Honduras). Their payment is between 1000-3000 \$ per month. At the bottom of the pyramid take place the locals (Iraq, Afghanistan), who are paid the worst. ${ }^{71}$

If we strictly look at the payments of private military company employees in comparison to payment of soldiers who undertake similar tasks at an army, we can say that the difference is really significant. In 2007, a private security man working at for instance Blackwater or DynCorp could even earn $1.222 \$$ per day (455.000 \$ per year). In comparison, a warrant officer earned 140-190 \$ per day (51-69.000 \$ per year). ${ }^{72}$ These numbers are only suitable for comparison at first sight indeed, as the $1.222 \$$ is the billing rate, not the amount that is actually paid for employees ${ }^{73}$ Besides the employee's payment, billing rate also includes indirect charges of private companies, overhead charges, and profit. ${ }^{74}$ As a result of this, employees only get about quarter or fifth of that amount which was paid for the private service by the contractor. ${ }^{75}$

Finally, we have to ask the question that from what amount does payment of private military company employees exceed significantly the amount paid for soldiers of armed forces. Based on our opinion, it is possible that some contractors meet the above-mentioned criteria, however, they can be parted from mercenaries when investigating motivational elements.

70 See Singer, P. W.: Corporate Warriors. The Rise of the Privatized Military Industry. IthacaLondon, 2003, 77; Schreier, F.-Caparini, M.: Privatising security: law, practice and governance of private military and security companies. Geneva Centre for the Democratic Control of Armed Forces, Occasional Paper, (2005) 6, 20-21; Salzman, Z.: Private Military Contractors and the Taint of a Mercenary Reputation. New York University Journal of International Law and Politics, 40 (2008) 3, 885; Dickinson, L. A.: Military Lawyers, Private Contractors, and the Problem of International Law Compliance. New York University Journal of International Law and Politics, 42 (2010) 2, 375-376.

71 Del Prado: op. cit. 437.

72 Stiglitz, J. E.-Bilmes, L. J.: The Three Trillion Dollar War-The True Cost of the Iraq Conflict. New York, 2008. 12.

${ }^{73}$ Huskey, K. A.: The American Way: Private Military Contractors \& U. S. Law After 9/11. PRIV-WAR National Report Series, 2010. http://priv-war.eu/wordpress/wp-content/uploads/2010/12/ nr-03-10-USA.pdf (06. 06. 2013.) 10.

74 The Congress of the United States-Congressional Budget Office: Contractors' Support of U. S. Operations in Iraq, 2008, August http://www.cbo.gov/sites/default/files/cbofiles/ftpdocs/96xx/ doc9688/08-12-iraqcont ractors.pdf (06. 06. 2013.) 14.

75 Karácsony: op. cit. 9. 
d) Nationality and place of residence

Based on Article 47 para. 2 of Additional Protocol I, Article 1 para. 1 of African Union Convention and Article 1 para. 1 of UN Convention the fourth element of the notion of mercenaries refers to their citizenship and state of residence. Based on this, mercenaries are people, who are "neither a national of a Party to the conflict nor a resident of territory controlled by a Party to the conflict". Article 1 para. 2 of UN Convention does not broaden the notion for armed conflicts when it rules that someone counts as a mercenary in any other situation who is neither a national nor a resident of the State against which such an act is directed.

According to Louise Doswald-Beck, it is not at all clear whether this condition applies to the PMC's state of incorporation (in which case all its members would be treated as having that nationality) or the nationality of the individual member or both as private military companies did not mean a problem when the Additional Protocol I was accepted. ${ }^{76}$

Based on the fourth element of the notion, besides that the aim they serve is acceptable by international law and morally, those who are citizens or residents of any of the fighting parties cannot be regarded as mercenaries. ${ }^{77}$ This conceptual notion was highly criticised based on its applicability in case of private military companies, as it leads to a totally illfounded conclusion between citizens and residents of the fighting states and between citizens and residents of other states. ${ }^{78}$ For instance: referring to the Afghanistan war, this conceptual notion excludes citizens and residents of the USA, Great Britain and Afghanistan from the notion of mercenaries, not employees from Honduras or Chile (only if they meet the other conditions).

According to the latest data, 113.376 contractors are employed in Afghanistan, out of which 30.568 are US citizens, 35.118 are citizens of a third state and 48.050 are citizens of Afghanistan. ${ }^{79}$ This means that at least $70 \%$ of private military company employees in Afghanistan fall outside of the notion of mercenaries.

Besides, it often is a part of private military company contracts that their employees obtain the citizenship of the contracting state, hence, they also fall outside the international legal regime referring to mercenaries. ${ }^{80}$

\section{e) Membership of the armed forces}

Based on Article 47 para. 2 of Additional Protocol I, Article 1 para. 1 of African Union Convention and Article 1 para. 1 of UN Convention the fifth element of the notion of mercenaries is membership of the armed forces of the fighting parties as a negative element. Hence, one can be regarded as a mercenary who is not member of the armed force of any of the fighting Parties; and has not been sent by a State which is not a Party to the conflict on official duty as a member of its armed forces. Article 1 para. 2 of UN Convention says similar, as based on this, a mercenary is a person who has not been sent by a State on

76 Doswald-Beck: op. cit. 9.

77 Sandoz-Swinarski-Zimmermann: op. cit. 580.

78 Gillard: op. cit. 569.

79 Contractor Support of U.S. Operations in USCENTCOM AOR, Iraq, and Afghanistan (July 2012). http://psm.du.edu/media/documents/reports_and_stats/us_data/dod_quarterly_census/ dod_quarterly_census_jul_2012.pdf (2013.06.12.).

80 See HC 577 Private Military Companies: Option for Regulation 2001-2002, Foreign and Commonwealth Office. http://www.fco.gov.uk/resources/en/pdf/consultations-mercenaries (2013.06.12.) 7 . 
official duty; and is not a member of the armed forces of the State on whose territory the act is undertaken.

Employees of private military companies act not as individuals but as parts of that organisation which lead their activity. Furthermore Singer highlights that employees have responsibility for their bosses, who have contractual obligations for their employers. That is, when the employer is a state, private military companies quasi act as national deputies on international stage. ${ }^{81}$ Moreover, Green calls upon that if the force that the mercenary offers his help to is an organised force, then mercenaries are most likely members of that organised force, and this also pulls it out from the notion of a mercenary. ${ }^{82}$

It follows from this that we can regard private military employees as members of armed forces. This is also understated by the contract cited by Singer, which was made between Sandline International and Papua New Guinea, in which employees of private military services were named "special soldiers" and were looked upon as part of armed forces. ${ }^{83}$ Which is even more significant, PMSC so much integrated into US security system that in 2006, the US Department of Defense regarded them as "total force" in the Four-year Defense Investigation issued by the Department of Defence. According to the document, the Department of Defence is the greatest employer of the world, as it has more than 3 million direct employees. Parts of "total force" are Active Component, Reserve Component, civilians and contractors that is PMSCs. ${ }^{84}$

\section{Conclusion}

The aim of the study that we worded in the introduction was to demonstrate the applicability of international legal regulations in connection to mercenaries to private military services. The most significant question was that whether we can put contractors under the notion of mercenaries with all of its consequences?

The answer to this question can be that every single element of the notion of mercenaries only comes true on very rare occasions. It is a conjunctive conceptual notion, so missing even one conceptual element makes the application of the rules to mercenaries impossible. As we noted in the study, the first two elements (recruiting and direct participation in hostilities) are accomplished by the contractors. In case of motivation-not counting the pre-condemned complicated and hard questions of demonstration-there is a possibility to draw a line between employees of private military companies and mercenaries. Nationality and membership of the armed forces as negative criterion places most contractors outside the international legal concept of mercenaries.

As a conclusion we can say that employees of private military companies can be regarded as mercenaries only on the rarest occasions. However, this conclusion leads to another question, namely that if they cannot be regarded as mercenaries, then what rules apply to them from international legal point of view? Whether they are combatants, civilians or maybe something else?

${ }^{81}$ Singer, P. W.: War, Profits and the Vacuum of Law. Columbia Journal of Transnational Law, $42(2005) 2,532$.

82 Green, L. C.: The contemporary law of armed conflicts. Manchester University Press, Manchester, 2000. 115-116.

83 Singer: War, Profits... op. cit. 532-533.

${ }^{84} 2006$ Quadrennial Defense Review, Department of Defense. http://www.defense.gov/qdr/ report/Rep ort20060203.pdf (12. 06. 2013.) 75. 